Journal of Nepal Geological Society, 2019, vol. 58 (Sp. Issue), pp. 97-103

DOI: https://doi.org/10.3126/jngs.v58i0.24592

\title{
Geology and mineral resources of Khudi-Bahundanda area of west-central Nepal along Marshyangdi Valley
}

\author{
*Shashi Tamang ${ }^{1}$, Sandeep Thapa ${ }^{1}$, Kabi Raj Paudyal ${ }^{1}$, Frédéric Girault ${ }^{2}$, and Frédéric Perrier ${ }^{2}$ \\ ${ }^{1}$ Central Department of Geology, Tribhuvan University, Kirtipur, Kathmandu, Nepal \\ ${ }^{2}$ Institut de Physique du Globe de Paris, Sorbonne Paris Cité ', Université Paris Diderot, CNRS, Paris, France
}

*Corresponding author: stamang39839@gmail.com

\begin{abstract}
Geological study was carried out along the Khudi-Bahundanda area of the Marshyangdi Valley in the west central Nepal. The area lies partly in the Main Central Thrust (MCT) zone and partly in the Higher Himalayan Crystalline Zone. The aim of the study was to prepare a detail geological map and cross section in the scale of 1:25,000 to work out on stratigraphy, metamorphism and mineral resource potential of the area. The rocks of the Higher Himalaya have been mapped under a single unit as Formation I. This unit consists of kyanite-garnet para-gneiss. The lithological units of the MCT zone are mapped into three units as the Benighat Slate, the Malekhu Formation and the Robang Formation from the bottom to the top, respectively. The Benighat Slate consists of dark grey to black schist with some carbonate beds as members. The Malekhu Formation consists of creamy white siliceous dolomite marble with parting of schist. The Robang Formation comprises of light grey psammitic schist with garnet and white micaceous quartzite in various proportion.

Many secondary structures are observed in the study area, but primary structures are missing due to extreme metamorphism. The large-scale structures are the MCT, which separates the Lesser Himalayan rocks to the south from the Higher Himalaya to the north, and the Bahundanda Thrust (BT). Numerous outcrop-scale structures like meso-scale folds, quartz veins, boudinage and ptygmatic folds are abundant. Folds in the MCT zone are mostly E-W trending, and rocks have experienced multiple metamorphism and dynamic crystallization of minerals. The Lesser Himalayan rocks resemble the garnet zone while the Higher Himalayan rocks resemble to the kyanite grade of metamorphism. As in the other sections of the Himalaya, the present section also clearly shows the inverted metamorphism in the MCT zone. The MCT zone is considered as the potential site for precious and semi-precious stones, of which the most potential ones are the garnet and kyanite.
\end{abstract}

Keywords: MCT zone, Metamorphism, Shear sense indicators, Gemstones, Marshyangdi Valley

Paper Received: 15 Dec 2018

Paper Accepted: 7 Apr 2019

\section{INTRODUCTION}

The present study area lies litho-tectonically in the Higher Himalayan Crystalline Zone and the Lesser Himalaya, which are separated by a thrust called the Main Central Thrust (MCT). The study area lies between the latitude of $28^{0} 30^{\prime} 00^{\prime \prime}$ to $28^{0} 15^{\prime} 00^{\prime \prime}$ and longitude of $84^{0} 30^{\prime} 00^{\prime \prime}$ to $84^{0} 20^{\prime} 00^{\prime \prime}$ in the Lamjung District (Fig. 1). The concept of the MCT was first proposed by Heim and Gansser (1939) in the Kumaun Himalaya to separate the overlying higher-grade metamorphic rocks as mica schists and gneisses from the underlying lower carbonate autochthon. He described that the upper MCT is the tectonic Boundary separating the Higher Himalaya with the Lesser Himalaya. Nanda (1973) established the lithostratigraphy of the Lesser Himalaya and the Higher Himalaya at Kali Gandaki section. Colchen et al. (1980; 1986) carried out the geological mapping around central Nepal including the Marsyangdi section in 1: 100,000 scale but the distinguished litho-units are too broad and can be further classified into different stratigraphic units in the present study section. Dhital (2015) carried out the geological survey around the Marsyangdi-Nadi confluence and categorized the rock succession of the area into the garnet schist, graphitic schist and carbonate unit on the footwall of the MCT and into the kyanite schist and quartzite, and augen or banded gneiss unit in the hanging wall based on the dominant lithology. He also clarified that the rock of the area belongs to the northern Limb of the Gorkha-Kuncha Anticlinorium. Le Fort (1975), Pêcher (1977; 1989), Rai et al. (1998) and Thapaliya and Paudel (2011) carried out geological study and explained about inverted metamorphism in the MCT zone. Paudel and Arita (2000) and Chamlagain et al. (2003) carried out the geological mapping respectively in the Lesser Himalaya in central Nepal and in eastern Nepal, and concluded poly-metamorphic phase in the Lesser Himalaya.

In the present study, a detail geological mapping of Khudi-Bahundanda area was carried out in the scale of 1:25,000. The lithostratigraphic classification of the area was established based on new findings. Geological structure of the area was studied to find out deformation history. A prognostic map was 


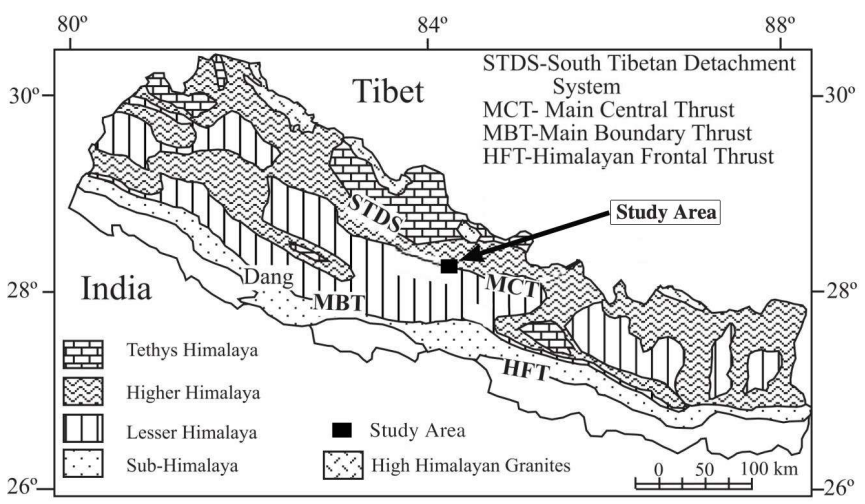

Fig. 1: Location map of study area

prepared and the potential metallic and semiprecious stone were indicated to be applicable for the reconnaissance survey during mineral prospecting.

\section{LITHOSTRATIGRAPHY}

The Higher Himalaya consists of only one unit, the Formation I that comprises rock succession of garnet-kyanite gneiss and mica schist. The MCT zone includes the rock succession from the Lesser Himalaya viz. a) the Benighat Slate b) the Malekhu Formation and c) the Robang Formation from the bottom to the top, respectively. In the Lesser Himalaya section, the grade of metamorphism is quite higher than that in the type locality, where mainly slate, phyllite, quartzite and dolomites exist. However, in the study area, they are metamorphosed into schist, foliated quartzite and dolomite marble (Fig. 2).

The Higher Himalaya comprises of high-grade metamorphic rocks such as gneiss and schist. Only the Formation I of the Higher Himalaya is mapped out in this study. The lower succession of this unit consists of garnet and kyanite paragneiss and mica schist. The middle part of this unit consists of paragneiss with abundant blades of kyanite and garnet. The size of garnet varies from about $2 \mathrm{~mm}$ to $2 \mathrm{~cm}$ in diameter and the blade of kyanite varies from about $2 \mathrm{~cm}$ to $10 \mathrm{~cm}$ in length. The uppermost part of this unit consists of paragneiss with the banding of schist with garnet and small proportion of kyanite.

The Lesser Himalaya in the study area is represented by the Benighat Slate, the Malekhu Formation and the Robang Formation in stratigraphic upward (Stöcklin and Bhattarai, 1977; Stöcklin, 1980). In the type locality, they are mainly slate, phyllite, quartzite and dolomites. However, in the study area, they are metamorphosed into schist, foliated quartzite and dolomite marble. The study area mainly consists of highly deformed garnet schist and laminated quartzite, black schist and carbonate beds (Fig. 3) bounded by footwall of the MCT towards north.

The Benighat Slate is well-exposed in Thakan, Rabagaun and Dhagai area, and mainly consists of black to dark grey schist with thin-beds of metasandstone and carbonate. The lower part of the rock succession consists of dark grey to greenish medium- to fine-grained schist. Thinly-bedded, Medium-grained, grey meta-sandstone is occasionally observed in between the schist. In addition, the band of meta-basite of about $5 \mathrm{~m}$ is observed concordant to the bed of schist to the south of Bhulbhule at about $1 \mathrm{~km}$. The middle part consists of dark grey to black, fine-grained schist with calcareous schist near the carbonate bed, whereas, the upper part of the formation mainly consists of black schist with garnet and intercalation of grey metasandstone. The size of garnet ranges from few $\mathrm{mm}$ to 1 $\mathrm{cm}$ in diameter. Garnets can only be observed in the uppermost part of this unit.

The lower part of the Malekhu Limestone comprises of calc-schist with thin bands of carbonate beds. The middle part consists of medium-to thick-bedded creamy-white grey siliceous dolomite marble with parting of phyllite. Most of the areas monotonously comprised of dolomite marble with parting of phyllite. The bands of white dolomite and quartzite are occasionally seen in some area and the strong lamination of phyllite can be observed throughout the rock succession. The uppermost part of the rock succession consist of siliceous dolomite marble with intercalation of dark grey calc-schist and light grey to greenish grey schist. The proportion of schist increases as we move towards the top of the unit. The strong stretching lineation can be observed in the schist.

The Robang Formation consists of garnet schist with intercalation of quartzite. The lower part consists of light grey garnet schist with small bands of white medium-grained quartzites. The schist is highly foliated and lineated. The middle part of this formation comprises of light grey to white, mediumto-thick beds of quartzite with intercalations of thin bands of garnet schist. Gradually, the proportion of quartzite decreases towards the top this unit. The size of garnet also increases towards top i.e. towards north. The size of garnet ranges from about $2 \mathrm{~mm}$ to $2 \mathrm{~cm}$ in diameter. The weathering color of the rock is mainly saffron in color.

\section{GEOLOGICAL STRUCTURE}

The MCT is the main large-scale structure characterized by change in lithology with respect to mineral present in it. The southern area of the MCT consists of garnet schist and quartzite whereas the northern zone consists of gneiss with kyanite and garnet. On the basis of sudden change in lithology along with the mineral isograde, the MCT is placed in between these two zones. In addition to change in lithology, fault related features like abundant quartz veins, drag folds, presence of hot springs, etc. are other indicators of the MCT. Similarly, the Bahundanda Thrust (BT), which trends E-W at Bahundanda, brought the older Benighat Slate and the Malekhu Formation over the younger Robang Formation. Furthermore, other structures such as meso-scale folds (Fig 4), drag folds, quartz boudinages and quartz veins (Fig 5) are well exposed in the outcrop of the Higher Himalaya and the Lesser Himalaya in different area. 


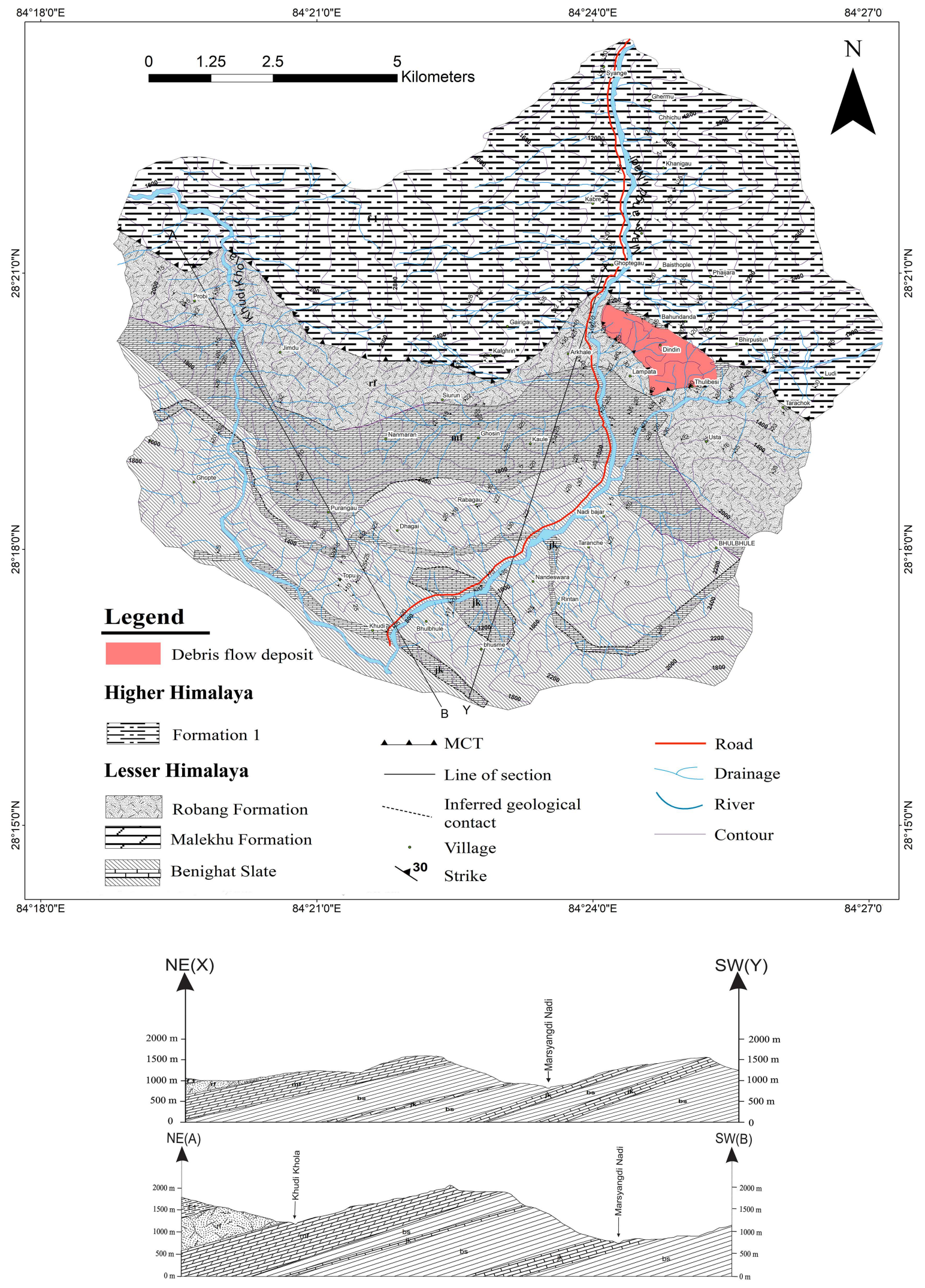

Fig. 2: Geological map of Khudi-Bahhundanda area of west central Nepal along Marshyangdi valley 


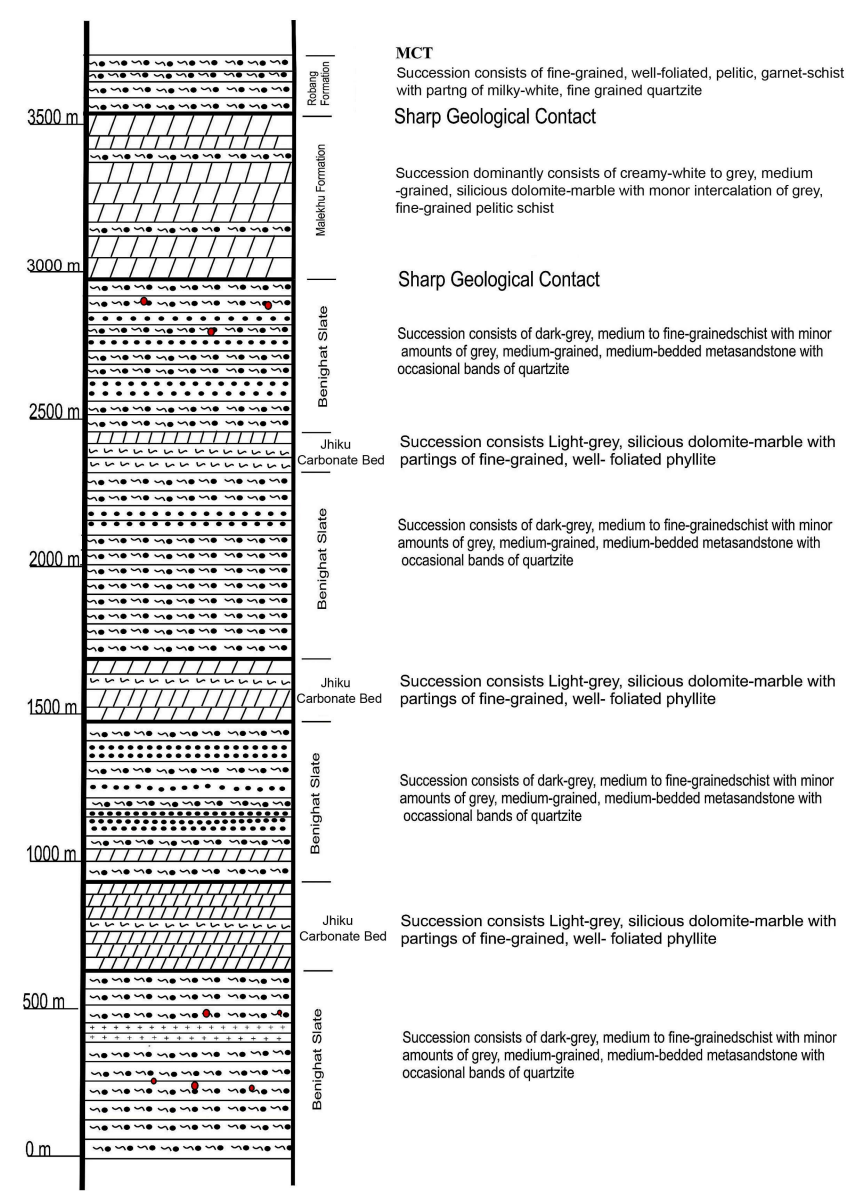

Fig. 3: Generalized columnar section of Khudi-Bahundanda area

Folds in the MCT zone are mostly E-W trending while the shear-sense indicators show top-to-south movement.

\section{METAMORPHISM}

Evidence of poly-metamorphism by recrystallization and cross-cutting relation of the mica flakes and reaction of garnets on its boundary is observed. In the rock sequence of the Higher Himalaya, the kyanite and garnet rich paragneiss with one set of foliation is observed. This could be resulted from prograde metamorphism at high pressure and temperature, which can be inferred as the first phase metamorphism. Furthermore, dynamic texture such as elongated garnet, rotated garnet, and bended kyanite blade is observed. Such texture shows the second stage of metamorphism, and occurred due to the activity of the MCT by the action of regional shearing and thrusting. The third type of metamorphism is shown by the retrogressive alteration of high-grade mineral like kyanite and garnet into low-grade biotite and muscovite. The rocks of the Higher Himalaya have undergone to Kyanite grade of metamorphism. This zone is distributed at the northern part of the MCT zone (hanging wall of the MCT) of the study area.
The polyphase metamorphism can be observed in the Lesser Himalayan rock succession also. The first phase metamorphism could be related to burial regional metamorphism, which produced foliation parallel to bedding plane, observed in the rock succession of the Nawakot Group. The second phase of metamorphism could be explained by the strong deformation of rock and increased grade of metamorphism near the MCT zone. The grade of metamorphism has increased gradually from south to north, toward the MCT. The older stratigraphic unit of the Nawakot Group has low-grade of metamorphism as compared to the rock succession towards younger one of the same successions. Hence, the inverted metamorphism is observed in the Lesser Himalaya rock of the present study area. Only one type metamorphic zonation i.e. garnet zone is observed in the rocks of the Lesser Himalaya section.

\section{MINERAL RESOURCES}

The area consists of metallic, industrial and semi-precious gemstone as the mineral resources. The copper is only the metallic mineral observed. The occurrences of malachite mineralization (copper ore) are mainly associated with the siliceous dolomite marble of the Robang Formation. Presence of copper showings is well indicated by the colorful leaching of malachite (green) in the outcrops. Similarly, garnet (Fig 6) and kyanite (Fig 7) are abundant in the study area. Therefore, the preferred dimension gem quality of the kyanite and garnet can be used as the gemstone otherwise they can be used as the industrial mineral to manufacture different materials such as abrasive, water jet cutting, electrical insulator and spark plug of vehicles.

\section{Garnet}

The study area also consists of significant amount of well-developed garnet with reddish brown in color. The hardness is about 6.5 to 7.5. The garnet can be observed in schist of the Robang Formation and also in the Higher Himalaya gneiss. The well-developed garnet is mainly concentrated along the MCT zone. The diameter of garnet ranges from about $2 \mathrm{~mm}$ to $2 \mathrm{~cm}$. The total resource of garnet, of the units of the Lesser Himalaya could be $9.756 * 109$ pieces. The total resource of garnet, of the units of the Higher Himalaya could be $1.096 * 1011$ pieces.

\section{Kyanite}

The occurrences of kyanite are concentrated along the MCT zone. The color of kyanite is light blue to inky blue and the size of kyanite ranges from $2 \mathrm{~cm}$ to $10 \mathrm{~cm}$ long along caxis. The distribution of kyanite is not uniform all around. There is variation in size, thickness and color. The total resource of kyanite, of the units of the Higher Himalaya could be $8.531 *$ 1010 pieces. Well-developed and tabular inky blue kyanite is used as gemstone. It can also be used to manufacture spark plug and high refractory porcelain. 


\section{DISCUSSIONS}

The study carried out presently is focused on geology and mineral resources of the Khudi-Bahundanda area. The study area comprises of rock succession similar to the Upper Nawakot Group (Stöcklin and Bhattarai, 1977; Stöcklin, 1980) of the Lesser Himalaya in central Nepal and kyanite garnet mica gneiss of the Higher Himalaya (Formation I of Le Fort, 1975). These two different rock successions are separated by a thrust called as the MCT.

The rock succession of the Higher Himalaya of present study area is represented by garnet and kyanite paragneiss. The size of kyanite ranges from $2 \mathrm{~cm}$ to $10 \mathrm{~cm}$ in length. The size of kyanite increases toward the north succession of rock up to few kilometers but again the size gradually decreases on moving towards north. It can be correlated with the Formation I of Le

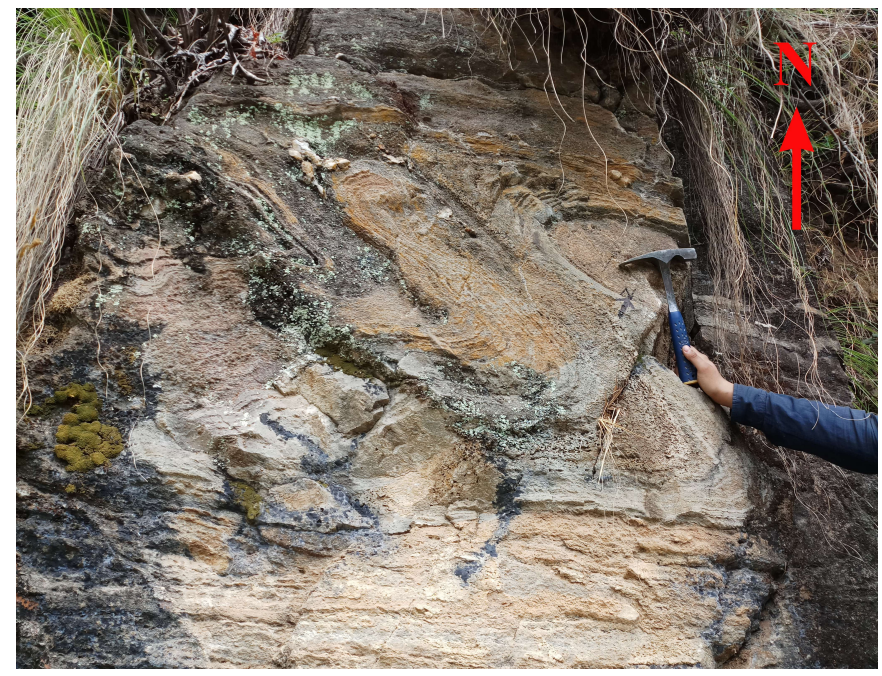

Fig. 4: Fold observed in the dolomite marble at Bahundana

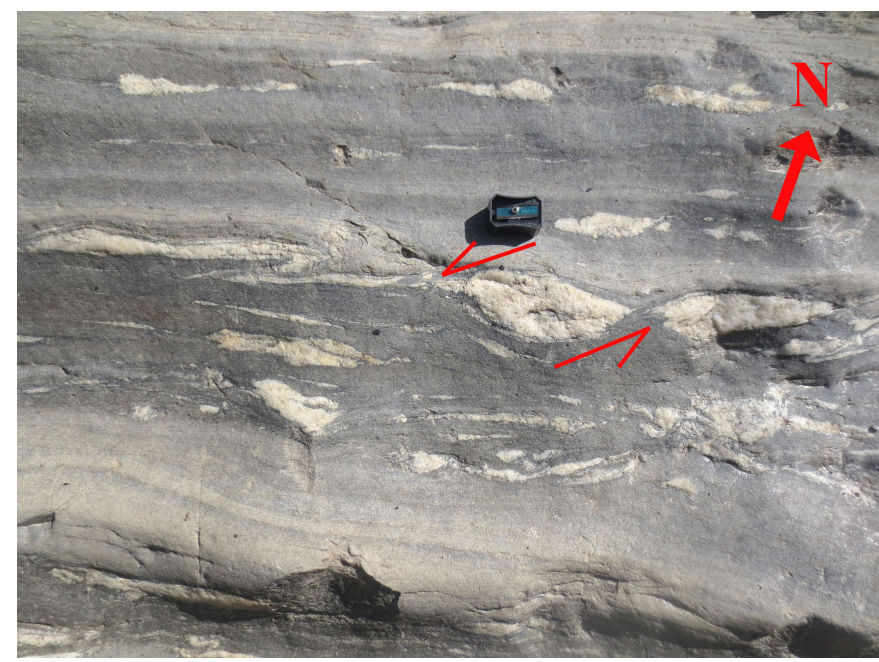

Fig. 5: Quartz vein along with asymmetric boudin showing the shear-sense indicators top-to-south movement
Fort (1975). The established rock units of the Lesser Himalaya are equivalent of the rock Units of the Nawakot Group but they are metamorphosed to high-grade as compared to type locality in Central Nepal. The rock succession in the study area of the Lesser Himalaya is divided into three-formation viz. (a) the Benighat Slate (b) the Malekhu Formation and(c) the Robang Formation from bottom to top respectively. The Benighat Slate comprises mostly dark grey to black schist with intercalation of few beds of quartzite and carbonate beds. It can be correlated with the graphitic schist and garnet schist of Dhital (2015). Similarly, it can be correlated with black schist of the Kaligandaki section of Upreti (2005). The Malekhu Formation overlies the Benighat Slate with sharp contact and predominantly consists of siliceous dolomite marble with parting of schist and calcschist with few inter-banding of quartzite also. It can be correlated with the Malekhu Limestone of Stöcklin (1980) in Central Nepal

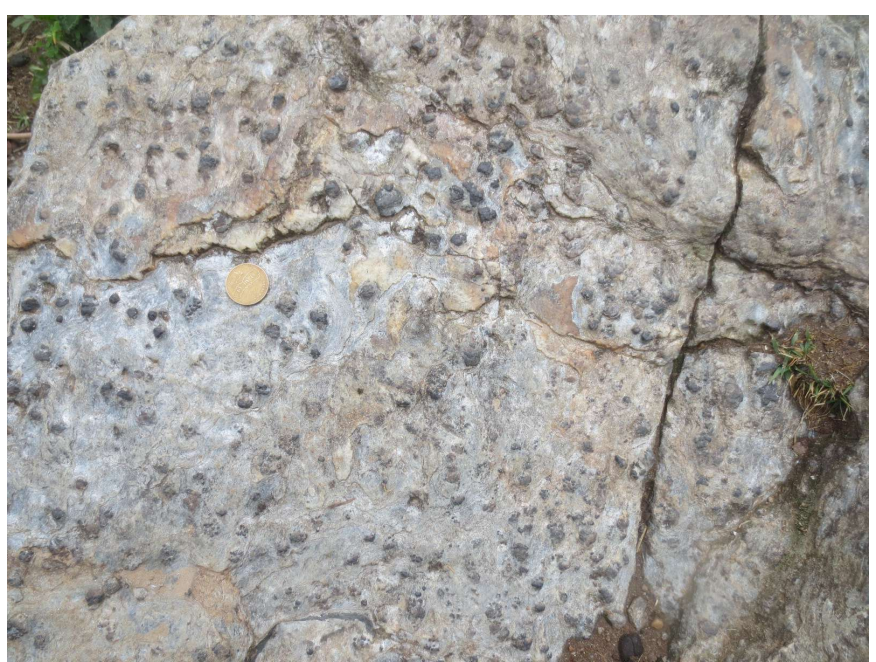

Fig. 6: Garnet crystal at schist of the Robang Formation

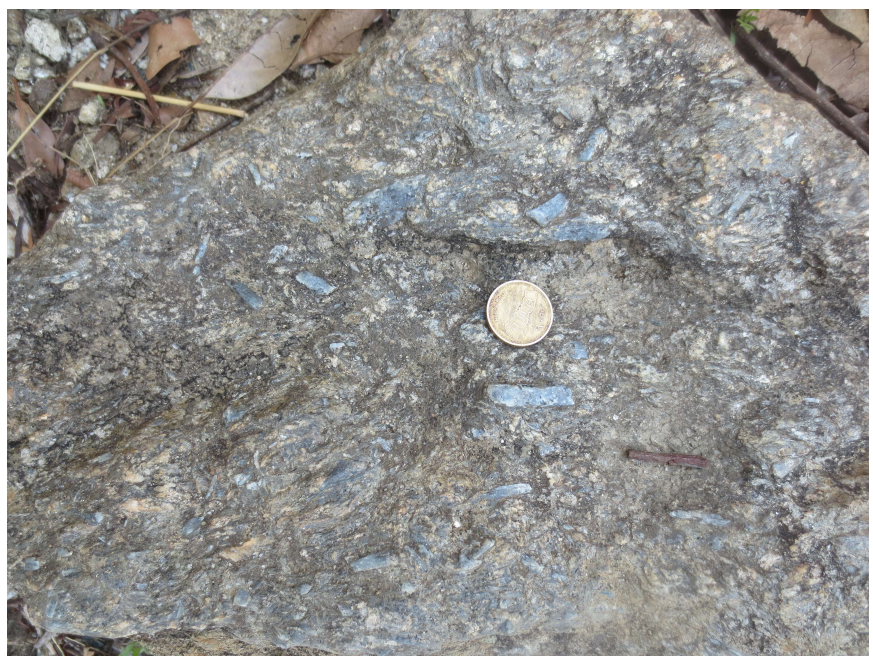

Fig. 7: Kyanite crystal odserved in gneiss of the Higer Himalaya 
and with carbonate band of Dhital (2009). However, this unit is absent in the Kaligandaki section. The Robang Formation is represented by the intercalated succession of micaceous quartzite and garnet schist which overlie the Malekhu Formation.

Furthermore, significant amount of garnet and kyanite can be observed in the Higher Himalaya section and the Lesser Himalaya rock succession. They can be used as semi-precious gemstone by doing quality check. In the study area, the garnet is mainly found in gneiss of the Higher Himalaya and in schist of the Lesser Himalaya (i.e. upper part of the Robang Formation). The color of garnet in study area is mainly reddish brown in color. The size of garnet ranges from $2 \mathrm{~mm}$ to $2 \mathrm{~cm}$ in diameter. The hardness is about 6.5 to 7.5. Garnet is used as semi-precious gemstone and abrasive (DMG, 2004). Only the perfect crystal of garnet can be used as gemstone, the fractured one is used in manufacturing abrasive, ceramics etc.

In study area, kyanite is observed in the rock succession of the Higher Himalaya in rocks like gneiss and schist, in which kyanites are light blue to inky blue in color and range from 2 $\mathrm{cm}$ to $10 \mathrm{~cm}$ in length along c-axis. Elongated tabular inky blue kyanite crystals could be cut for gemstone (Kaphle, 2011). It is also use in the manufacture of spark plugs and other high refractory porcelain.

\section{CONCLUSIONS}

A detailed geological map and cross-section of the study area is prepared in the scale of 1:25,000 and the two units from the Nawakot Group were established. The Lesser Himalayan rock can be mapped under three units as named as (a) the Benighat Slate (b) the Malekhu Formation and (c) the Robang Formation from older to younger stratigraphy, respectively. The rock succession of the Higher Himalaya comprises of garnetkyanite paragneiss. The study area has gone through multiple metamorphism and dynamic crystallization of minerals. The Lesser Himalayan rocks resemble the garnet grade of metamorphism while the rocks of the Higher Himalaya resembles to the Kyanite grade of metamorphism. The rocks of the Lesser Himalaya have shown poly-metamorphic events. Both the preMCT and the post-MCT metamorphic events are well-recorded in the rocks. As in the other sections of the Himalaya, the present section also clearly shows the inverted metamorphism in the MCT zone. Malachite mineralization in trace amount is observed in the Malekhu Formation of the Lesser Himalayan unit. Reddish brown garnet with diameter ranging from $2 \mathrm{~mm}$ to $1.5 \mathrm{~cm}$ and hardness ranging from 6.5 to 7.5 is found in the Lesser Himalaya and the Higher Himalaya. The total reserve of garnet, of the units of the Lesser Himalaya could be $9.756 * 109$ pieces. Inky blue to light blue kyanite, length ranging from $2 \mathrm{~cm}$ to $5 \mathrm{~cm}$ is observed in the rock succession of the Higher Himalaya. The total resource of kyanite, of the units of the Higher Himalaya could be $8.531 * 1010$ pieces. The total resource of garnet, of the units of the Higher Himalaya could be $1.096 * 1011$ pieces.

\section{ACKNOWLEDGMENTS}

The current study belongs to the outcomes of Master's degree thesis of the first author. Authors are thankful to Prof. Dr. L. P. Paudel, Central Department of Geology for providing facilities. Authors are also thankful to Institute de Physique du Globe de Paris, France for the grant and guidance.

\section{REFERENCES}

Chamlagain, D., Rai, S.M., and Hayashi, D., 2003, Geology, structure and metamorphism of Mai Khola area southern western part of Illam bazaar, Eastern Nepal. Bulletin. Fac.Sci., University of the Ryukyus, pp.55-74.

Colchen, M., Le Fort, P., and Pêcher, A., 1980, AnnapurnaManaslu- Ganesh Himal. Centre National de la Researches Scientifique, Special Publication, Paris, 136p.

Colchen, M., Le Fort, P., and Pêcher., A. 1986, AnnapurnaManaslu-Ganesh Himal notice de la carte géologique au 1/200,000è. Recherches géologiques dans l'Himalaya du Népal. Centre de Recherches Pétrographiques et Géochmmiques, Paris (In French and English).

Dhital, M. R., 2015, Geology of the Nepal Himalaya, Regional Perspective of the Classic Collided Orogen. Springer Cham Hedelberg, New York, 198p.

DMG 2004, Mineral Resources of Nepal, Prepared by Joshi, P. R., Rahman, H., Singh, S., Khadka, D. R., Napit, D., 154p.

Heim, A. and Gansser, A., 1939, Central Himalaya, geological observations of the Swiss expedition 1936. Mémoires de la Société Helvétique des Sciences Naturelles 73, Zürich, $245 \mathrm{p}$.

Kaphle, K.P., 2011, Minerals Resources of Nepal and their present status, Journal of Nepal Geological Society

Le Fort, P., 1975, Himalayas: the collided range, present knowledge of the continental arc. American Journal of Science, v. 275A, pp. 1-44.

Nanda, M.M., 1973. Progress report on geological mapping of Trisuli-Bazar area, Nuwakot and Dhading Districts, Bagmati Anchal, Nepal. Report, submitted to the Geological Survey of India. (with maps), unpublished. 31 p.

Paudel, L.P. and Arita, K., 2000, Tectonic and polymetamorphic History of the Lesser Himalaya in the centra Nepal. Journal of Asian Earth Sciences, pp. 10-24. https://doi.org/10.1016/S1367-9120(99)00069-3

Pêcher, A., 1977, Geology of the Nepal Himalaya: deformation and petrography in the Main Central Thrust Zone. In: Ecologie et Géologie de l'Himalaya, Colloques 222 Internationaux du Centre National de la Recherche Scientifique, Paris, v. 268, pp. 301-318.

Pêcher, A., 1989, The metamorphism in the central Himalaya. 
Journal of Metamorphic Geology, v. 7, pp. 31-41p. https://doi.org/10.1111/j.1525-1314.1989.tb00573.x

Rai, S.M., Guillot, S., Le Fort, P., and Upreti, B.N., 1998, Pressure temperature evolution in the Kathmandu and Goshainkund regions, Central Nepal. Journal of Asian Earth Sciences, Vol. 16, pp. 283-298. https://doi.org/10.1016/S0743-9547(98)00019-1

Stöcklin, J., 1980, Geology of Nepal in its regional frame. J. Geol. Soc. London, v. 137, pp. 1-34. https://doi.org/10.1144/gsjgs.137.1.0001

Stöcklin, J., and Bhattarai, K. D., 1977, Geology of Kathmandu Area and Central Mahabharat Range. Nepal Himalaya: Report of Department of Mines and Geology/NUDP (unpublished), $86 \mathrm{p}$.
Thapaliya, S., and Paudel, L. P., 2011, Inverted metamorphic zonation in the hanging and foot walls of the Mahabharat Thrust, Kathmandu- Trishuli area, central Nepal. Bulletin of Department of Geology, Tribhuvan University, Kathmandu, Nepal, v. 14, pp. 51-58. https://doi.org/10.3126/bdg.v14i0.5439

Upreti, B.N. and Le Fort, P., 1999, Lesser Himalayan crystalline napps of Nepal: problems of their origin. Geological Society of America Special Paper, v. 328, pp. 225-238.

Upreti, B.N. and Yoshida, M., 2005, Guidebook for Himalayan trekkers (Series No. 1): Geology and natural hazards along the Kali Gandaki valley. Department of Geology, TriChandra Campus, Tribhuvan University, 165p. https://doi.org/10.1130/0-8137-2328-0.225 
